\title{
Publicitatea din domeniul turismului și ciberspații ale călătoriei
}

\author{
Ana Crăciunescu* \\ Facultatea de Litere și Științe ale Comunicării, Universitatea „S, Stefan cel Mare”, Str. Universității 13, 720229 Suceava, România
}

\begin{tabular}{ll}
\hline Despre articol & Rezumat \\
Istoric: & În contextul globalizării cibernetice, noțiuni precum „spațiu” și „loc” sînt recon- \\
Primit 30 decembrie 2016 & siderate din perspectiva studiilor de consum și de antropologie. Ne propunem \\
Acceptat 19 ianuarie 2017 & să descriem spațiul și locul în lumina reclamei din domeniul turismului, întrucît \\
Publicat 23 martie 2017 & includem toate cele trei noțiuni în categoria fenomenelor sociale importante de \\
& astăzi. În același timp, mass-media apare în dezbaterea noastră ca un strat secun- \\
Cuvinte-cheie: & dar care poziționează potențialele gazde și potențialii turiști într-un tip de relație \\
publicitatea în turism & și percepție a spațiului și a locului diferit. Însă, sîntem preocupați în special de \\
spațiu & aspectul discursiv al cuplului spațiu-loc, în cadrul experienței turistice virtuale, \\
loc/non-loc & considerată o lectură prospectivă care ar putea genera schimb real în destinație. \\
ciberspațiu & Acest lucru ne va conduce, în mod inevitabil, la o cercetare interdisciplinară, \\
& întrucît vom urmări o echilibrare a studiului nostru între antropologie culturală \\
& și socio-semiotică.
\end{tabular}

\section{Introducere}

Virtualizarea locurilor turistice nu mai reprezintă o problematică nouă în dezbaterile specialiștilor de pretutindeni, întrucît internetul joacă un rol major în 'industria' informației, la fel ca în cazul efectelor de masă produse de marketing. În acest sens, internetul a devenit un obiect de studiu apreciat în cadrul teoriei enhancement-ului. Privit ca o prelungire artificială a minții și corpului uman, se consideră că internetul îmbunătățește la nivel cognitiv. Totuşi, rămînînd în mare parte tributar consumului, acesta își transferă, aşadar, funcțiile, la un nivel mai primitiv (vezi piramida lui Maslow).

În cazul turismului, internetul joacă rolul unui vehicul de bază, însă virtual, „îmbunătăţind” individul, care devine capabil să înceapă o călătorie prospectivă. Acest tip de spațiu este cunoscut drept ciberspațiu și definește toți atomii și conexiunile specifice acestei realități virtuale.

În această lucrare, ne propunem să demonstrăm în ce măsură reclama din domeniul turismului se produce ca un ciberspațiu sau în ce măsură aceasta poate fi reconsiderată din perspectiva noțiunii de nonloc (non-place), ca o consecință a ciberspațiului.

Situat la intersecția dintre antropologia culturală și socio-semiotică, studiul nostru aduce în atenție reclama din domeniul turismului ca o reconsiderare a discursului spaţial. Întrucît preocuparea noastră țintește atît o revizuire a nivelului conceptual (loc/non-loc, non-loc în non-loc), cît și a celui social (internetul), analiza noastră va avea un caracter interdisciplinar. Acest lucru ne-a condus către o metodologie de cercetare pe care o considerăm cea mai potrivită pentru astfel de cazuri: Analiza Discursului și constituirea corpusului (vezi studiul de caz).

Chiar dacă noțiunea centrală a demonstrației noastre—non-locul (non-place)—este definită în legătură cu o aprehensiune semiotică, ca un conglomerat al (non)semnificaţiilor, acest aspect este, totuşi, determinat de schimbările sociale pe care globalizarea le produce la toate nivelurile. Astfel, în acest punct, problematica semiotică se dizolvă pentru a lăsa locul observației aspectelor sociale și antropologice ale reclamei din domeniul turismului, incluzînd, de asemenea, idei din studiile de consum. Aceasta este, în definitiv, una din principalele trăsături ale socio-semioticii, căci, aşa cum afirmă T. van Leeuwen: „Sociosemiotica nu este teorie 'pură, nu este un studiu de sine stătător. Ea devine astfel doar cînd este aplicată

*Adresă de corespondență: anna_c00@yahoo.com. 
unor probleme sau instanțe specifice și întotdeauna necesită o imersiune nu doar în conceptele și metodele semiotice, dar ci şi în alte domenii” (Leeuwen, 2005, p. 13).

Pornind de la lingviști de referință, precum F. de Saussure, acest demers de cercetare calitativă este susținut de autori precum Lefebvre sau de Certeau, care sesizează aspectele de semnificație ale spațiului, fără a fi, totuși, angajați între granițele stricte ale semioticii. În final, M. Augé completează cadrajul conceptual dintr-o perspectivă recentă asupra societății postmoderne, conducîndu-ne către consecințele acesteia la nivel social și cultural, pe care le ating, de asemenea T. van Leeuwen și A. Appadurai.

\section{Reclama din domeniul turismului și utilizarea spațiului}

Afirmăm că reclama din domeniul turismului reprezintă o lectură prospectivă ${ }^{1}$ (Crăciunescu, 2015), pe care consumatorul/potențialul turist o realizează pentru a dezvolta un comportament de consum, după un proces decizional și motivațional. De altfel, în opinia noastră, reclama din domeniul turismului reprezintă, de departe, o fereastră de semnificații deschisă spre lume, care odată ce este descifrată de semioticianul amator (publicul), constituie o șansă a opțiunii, o 'prospectare' a pieței. Așadar, imperiul postmodern al alegerii, nu doar că răspunde dorinței, dar domnește cu succes într-o societate capitalistă ca un pilon, ceea ce conferă, într-o oarecare măsură, un alibi major publicității.

În ultimul timp, ciberspațiul incorporează atît publicitatea de tip print și audio-video, cît și social media și publicitatea online. Dar, mai întîi, pentru a defini ciberspațiul, trebuie să analizăm semnificațiile termenului spaţiu (space), care apare la autori precum de Certeau, Lefebvre și Augé în contrast sau în prelungirea termenului de loc (place). În acest fel, în opinia lui de Certeau, „un loc (lieu) este ordinea (de oricare tip) în acord cu care elementele sînt distribuite în relaţii de coexistență” [...] Un loc este, aşadar, o configurare instantanee a pozițiilor. Ea implică o indicație a stabilității” (de Certeau, 1984, p. 117). În cuvintele aceluiași autor, spațiul „este compus din intersecția elementelor mobile. Într-un sens, el este acționat de ansamblul mișcărilor desfăşurate în cadrul acesteia (ibid.). În cele din urmă, apropiind locul de spațiu, de Certeau afirmă că „spațiul ar putea fi pentru loc ceea ce cuvîntul devine atunci cînd este rostit” și că „spațiul este un loc practicat” (ibid.). În ceea ce privește obiectul nostru de studiu, de Certeau aduce lumină în demonstrația noastră, afirmînd că:

[...] un act de lectură reprezintă spațiul produs prin practicarea unui numit loc: un text scris, de exemplu, un loc constituit dintr-un sistem de semne. (de Certeau, 1984, p. 117)

Lefebvre (1991) realizează, de asemenea, că „termenii practicilor de zi cu zi servesc pentru a distinge [...] spaţii particulare” (p. 16). Mai mult, autorul implică, la rîndul său, aspecte lingvistice și discursive care ar putea conduce la ideea că „rezultatul gîndirii noastre ar putea fi construcția unui 'sistem al spațiului'” (ibid.). În final, Lefebvre atinge aceeași problemă ca de Certeau, în cazul spaţiului social, întrebîndu-se retoric dacă acesta ar trebui formulat, acompaniat sau precondiționat de limbaj (cf. ibid.), sau, așa cum am spune, în termeni saussurieni, dacă spațiul social este articulat.

Într-o viziune consumeristă, Augé (1995) critică supra-saturația termenului 'spațiu' în cazul brandurilor (populare) și a expozițiilor destinate a fi consumate, spre exemplu: "Espace Cardin”, "Espace Yves Rochers", "Renault Espace" etc. (p. 83):

Mania pentru cuvîntul 'spațiu' [...] exprimă nu doar temele care obsedează era contemporană (publicitatea, imaginea, timpul liber, libertatea, călătoria), ci și abstractul care le corodează și le amenință, ca și cînd consumatorii spaţiului contemporan ar fi invitaţi înainte de toate să se simtă bine prin cuvinte. (Augé, 1995, p. 83)

\footnotetext{
${ }^{1} \mathrm{O}$ sintagmă pe care am creat-o pentru a reda mai facil limbajul științific al decodificării și alegerii, pentru publicul larg. Pe scurt, aceasta rezumă relația dintre mesajul conținut de imaginea publicitară ca întreg (text, imagine) și lectura consumatorului, aproape ca un gest cultural postmodern. Un proces al semiozei, lectura prospectivă implică, așadar, în opinia noastră, o înțelegere și o practică semiotică (in)conștientă (și, prin urmare, culturală), îmbogățind, în același timp, lexicul economic, întrucît publicitatea rămîne, într-o mare măsură, o chestiune de marketing.
} 
Înțelegerea spațiului prin limbaj, sau dihotomia spațiu/loc văzută ca dihotomia limbă/vorbire, pe care o găsim la toți cei trei autori, subliniază ideea de spațiu organizat ca un discurs al locului. În cazul turismului, spațiul poate fi o imagine proiectată ca un rezultat al unui discurs pre-ambalat și organizat social într-un cadru virtual, adică, în cadrul ciberspațiului. Pe de o parte, credem că „imaginația joacă un rol important întrucît declanșează nevoia noastră pentru virtual (sau fanteziei într-o primă fază) și este responsabilă pentru stimularea dorinței de a călători. Ciberspațiul speculează escapismul ca o nevoie majoră pentru călătoria la nivel mental și experiența virtuală (Crăciunescu, 2014, p. 40). Pe de altă parte, „spațiul călătorului ar putea deveni, astfel, arhetipul non-locului" (Augé, 1995, p. 86).

Non-locul, ca noțiune opusă locului, definește un spațiu articulat, precum reclama din domeniul turismului manifestată ca și prin ciberspațiu. Chiar dacă non-locul este văzut ca un loc golit de semnificații, M. Augé îi reevaluează sensurile și rolurile în cadrul societății de consum. Acesta reprezintă o dimensiune naturală care apare ca o reacție la locul supra-articulat. În acest sens, am putea spune că non-locul capătă trăsăturile non-discursului ca opus discursului. Imaginea înlocuiește verbalul, și, astfel, dizolvă sensul prin valuri de mesaje nearticulate care trec granițele lingvisticului și, deci, ale spațiului. În comparație cu abundența informației care trece prin valurile de imagini către mișcarea contempornă a indivizilor, A. Appadurai afirmă că:

Lucrurile stau la fel atît în cazul medierii, cît și în cazul mișcării. Povestea migrației de masă (voluntară sau forțată) nu e o trăsătură nouă în istoria umanității. Dar atunci cînd este suprapusă mișcării rapide a imaginilor mediatizate, a scenariilor, a senzaţiilor, avem o nouă ordine a instabilității în producția subiectivităților moderne. (Appadurai, 1996, p. 4)

Aceste 'subiectivități moderne' sînt redimensionate prin privirea turistului (Urry, 2011), care se transformă tot mai mult recent, în cazul nostru, într-o privire care se inversează la orice moment al articulării în spațiu, mai precis, în destinația turistică. Problemele de gen sau de etnie care declanșează rolurile inversate ale privirii panoptice, emerg ca o producție a puterii care portretizează noile figuri ale subiectivităților moderne. Celălalt încă reprezintă o problemă cu un impact important în studiile de turism şi noi astfel posibilități de călătorie sînt privite prin lentilele media. Deși este o unealtă a globalizării, alteritatea ca producție turistică în termenii destinaţiilor exotice favorite, ar putea conduce, de asemenea, la uniformizare. Unii autori evocă „imperialismul cultural prin globalizare și omogenizare” (Machin \& Leeuwen, 2007, p. 23). Acest lucru înseamnă că atît articularea cît și non-articularea spaţiului prin mass-media, și, deci, prin spaţiu virtual (de exemplu, internetul) este o formă a riscului pe care locul ca marcă a autenticităţii o ia pentru a se diferenția, atît din punct de vedere cultural, cît și promoțional.

Totuşi, subiectivitățile moderne urmăresc sau mai degrabă compun tendințele turismului ca experiență, fie ea una exotică sau unică, așadar imaginea și imaginația ca factori non-articulatorii joacă un rol important în promovarea destinațiilor turistice. Nu doar că ciber-spațiul încorporeză locuri (non)articulate întro dialectică a virtualului, dar exprimă deopotrivă dimensiunea artistică a non-locului, ca un grad zero al culturii și simbolicului, în noua structură socială și de înțelegere a practicării spațiului.

\section{Spot publicitar Switzerland: un exemplu de virtualizare a (non)locului dublu stratificată}

O invitație în Vrin este lansată în aglomerata gară centrală din Zürich direct din destinație via utilizării ciberspațiului. Standul outdoor prinde viață dintr-o dată, întrucît internetul conectează gazda din Vrin la trecătorii din gară. Astfel, internetul aduce împreună gazda și potențialii turiști într-o experiență virtuală a lecturii prospective prelungită dincolo de un al doilea ecran, cel al media sau reclama în sine. Privirea turistului, ca spectator al acestui mesaj bine conceput la nivelul marketingului, sesizeză două straturi ale virtualului, întrucît acesta incorporează atît realitatea spațiului reclamei (spațiul din Vrin și spațiul gării) și realitatea ciberspațiului care mediatizează reclama (spațiul reclamei). 
Expunem mai jos cîteva capturi relevante pentru această situație a virtualizării non-locului dublu stratificată:
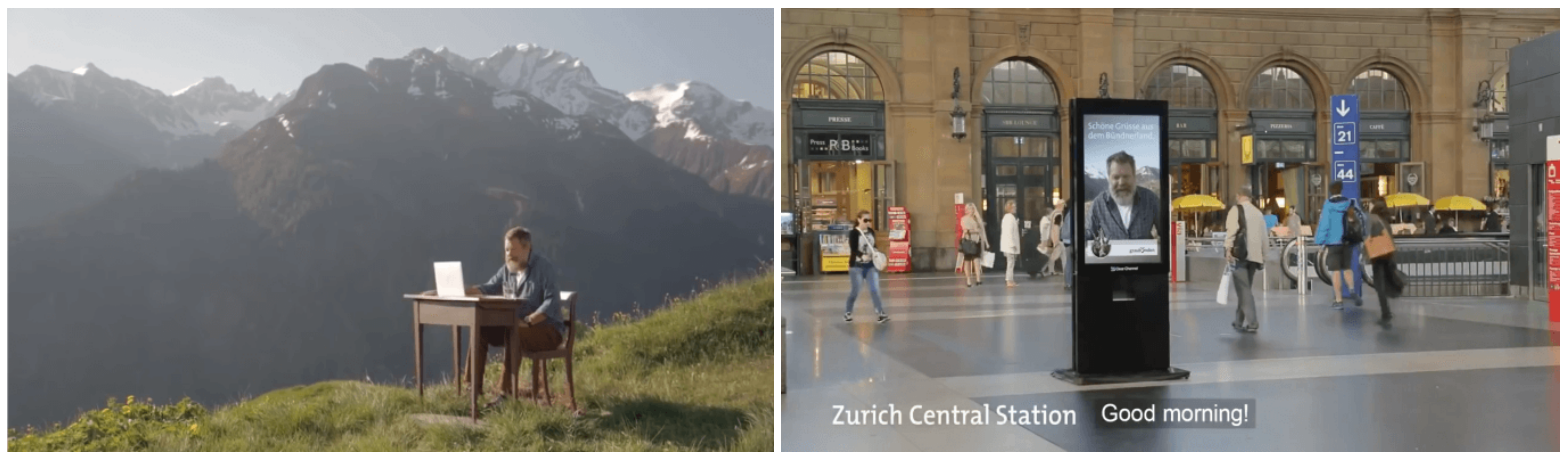

Figura 1: Capturi din spotul publicitar Switzerland, 2015 [online]

Interacțiunea directă dintre gazde și turiști este o acțiune a deteritorializării spaţiului, în timp ce granițele locului sînt șterse. Totuși, cel mai relevant semn al acestei articulări simultane și fără limite, a celor două spați diferite, este imaginea proiectată pe ecran a turiștilor care sosesc în destinație, ca o reproiectare în locul pe care l-au părăsit (gara). În termenii lui M. Augé, această imagine mediată este specifică nonlocului, adică a unei experiențe în spațiu care proiecteză imagine din loc (gara) în non-loc (imaginea de pe panoul outdoor: destinația turistică). În final, întreaga reclamă reprezintă un non-loc, în timp ce mediul potențialului turist este locul. În această logică, obținem diferite grade ale locului și non-locului. Totuși, în acest context, non-locul nu urmează ideea conform căreia acesta ar fi un loc golit de semnificații, ci, mai degrabă, a ciber-spațiului, a unui spațiu virtual reproiectînd locul în realități imaginate.
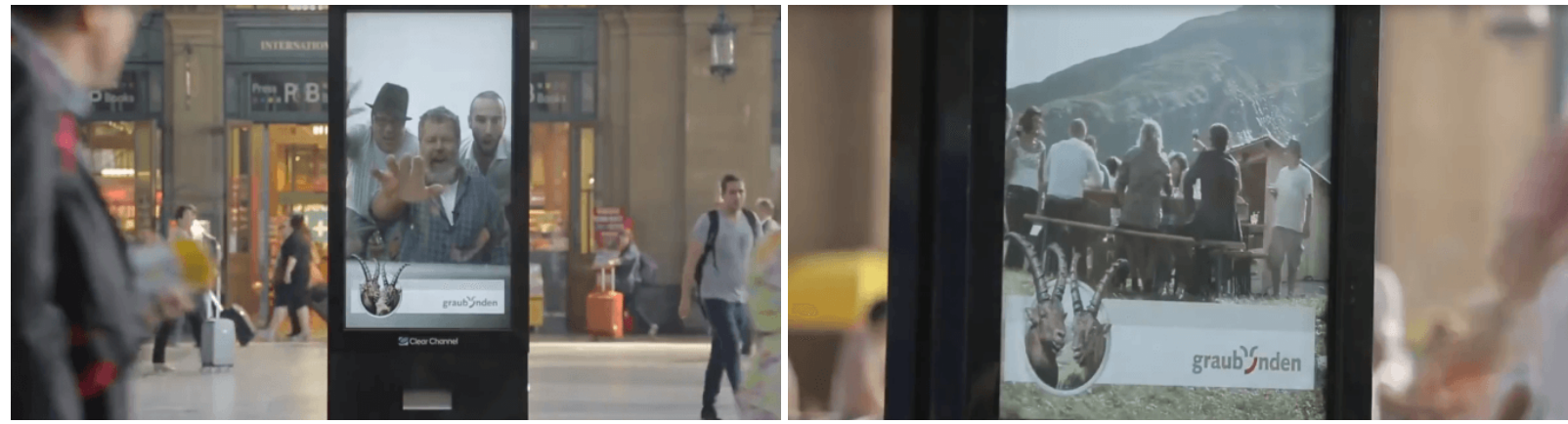

Figura 2: Non-loc în loc (Switzerland, 2015) [online]

\section{Concluzii}

Așa cum am putut vedea în studiul de caz, reclama din domeniul turismului nu este doar un exemplu al practicii discursive și ciberspaţiale recente, ci și un exemplu al non-locului în non-loc. Reclama din domeniul turismului ar putea fi considerată un limbaj virtual (non)articulat al spaţiului care incorporează și speculează locul la potențialul său maxim, în comparație cu orice alt produs. Nu doar că destinațiile turistice se dezvăluie prin discurs promoțional la nivelul ciberspațiului la distanța unui clic, dar acestea pot, de asemenea, să constituie o experiență virtulă a lecturii prospective care ar putea conduce la comportament consumatorist specific. În această lumină, sîntem tentați să apreciem că reclama din domeniul turismului ar putea, deopotrivă, să devină un patrimoniu virtual de amploare al locurilor autentice, transpus prin limbajul diferențirii non-locului. 


\section{Bibliografie}

Appadurai, A. (1996). Modernity at large. Cultural Dimensions of Globalization, University of Minnesota Press. Augé, M. (1995). Non-places. Introduction to an Anthropology of Supermodernity, Verso, London - New York. de Certeau, M. (1984). The Practice of Everyday Life, University of California Press.

Crăciunescu, A. (2014). (Re)branding cities. The culture of consuming places and virtual reiterations of space in promotional touristic websites, în "Anadiss", no. 18, p. 37-53.

Crăciunescu, A. (2015). O reinterpretare a icono-textului. Noi provocări ale publicității audio-video din turism, în Grădinaru, C. (ed.), From Manuscript to E-book, Editura Universității „Al. I. Cuza”, Iași, p. 331-339.

Leeuwen, T. (2005). Introducing Social Semiotics, Routledge.

Lefebvre, H. (1991). The Production of Space, excerpts, Blackwell Publishing.

Machin, D. \& Leeuwen, T. (2007). Global Media Discourse. A Critical Introduction, Routledge.

Switzerland, 2015 = Switzerland video commercial, 2015, [online] (accesat la 12 mai 2016).

Urry, J. (2011). The Tourist Gaze, Sage Publications Ltd. 